\title{
CHARACTERIZATION, CLASSIFICATION AND SUITABILITY EVALUATION OF SOILS UNDER SUGARCANE (Saccharum officinarum L.) CULTIVATION AT THE SUGAR RESEARCH FARM, UNIVERSITY OF ILORIN, NIGERIA
}

\author{
${ }^{1}$ Ajala O.N., ${ }^{* 2}$ Adjadeh T.A., ${ }^{1}$ Olaniyan J.O., ${ }^{1}$ Isimikalu T.O., ${ }^{2}$ Nartey E.K. and ${ }^{1}$ James F.O. \\ ${ }^{1}$ Department of Agronomy, University of Ilorin, PMB-1515 Kwara State, Nigeria \\ ${ }^{2}$ Department of Soil Science, University of Ghana, POBox-245 Legon, Accra, Ghana \\ *Corresponding author email: tadjadeh@ug.edu.gh
}

\begin{abstract}
A reconnaissance survey conducted at the University of Ilorin Sugar Research Farm (USRF) revealed four dominant soils at Site 1 (USRF1) and one at Site 2 (USRF2). The soils were characterized and classified according to both the Soil Taxonomy (ST) and the World Reference Base for Soil Resources (WRB). Also, the suitability of the soils for sugarcane cultivation was evaluated using the limitation approach. While the USRF1 soils were reddish, the USRF2 soil was greyish due to poor drainage. The USRF1 soils were loamy sand with the AB-horizons of pedons II and III being gravelly. Pedon V had sandy loam surface, sandy clay loam subsurface and clay loam subsoil. The USRF1 soils were moderately acid while the USRF2 soil was slightly acid to slightly alkaline. Exchangeable calcium $\left(\mathrm{Ca}^{2+}\right)$ content of the USRF2 soil which averaged $4.00 \mathrm{cmol}_{\mathrm{c}} \mathrm{kg}^{-1}$ was 2-3 times higher than that of the USRF1 soils. The USRF2 soil also contained higher $\mathrm{Mg}^{2+}, \mathrm{K}^{+}$and $\mathrm{Na}^{+}, 2-3$ folds higher effective cation exchange capacity and $>10$ folds higher soil organic carbon (with mean of $11.60 \mathrm{~g} \mathrm{~kg}-1$ ) and total nitrogen (mean of $0.94 \mathrm{~g} \mathrm{~kg}^{-1}$ ). Under ST, pedons I and IV classified as Typic Haplustepts, II and III as Lithic Haplustepts and V as a Kanhaplic Haplustalf. Under WRB, pedons I and IV classified as Eutric Regosols (arenic), II and III as Endo-pisoplinthic Cambisols (arenic) and $V$ as a Gleyic Lixisol (loamic). Pedon $V$ was highly suitable (85.25\%), I and IV moderately suitable (64.53\%), II marginally suitable (47.40\%) and III unsuitable (35.62\%) for sugarcane cultivation.
\end{abstract}

Key words: limitation approach, reconnaissance survey, soil suitability, sugarcane cultivation, UNILORIN

\section{INTRODUCTION}

Agriculture provides food for humans and domesticated animals, raw materials for industries and helps to accelerate economic growth of developing countries (Sajjad et al., 2014). Agriculture is the predominant economic activity in Nigeria because of the ever-increasing demand for food (Obasi et al., 2016). Consequently, there have been many studies on soil characterization and suitability for various crops including cashew (Olaniyan and Ogunwale, 2006), cocoa (Ajiboye et al., 2015), rice (Ajiboye et al., 2011; Osinuga et al., 2020) and cowpea (Ogunwale et al., 2009). Also, detailed information on soil properties is required to determine their potential for food, fodder and fiber production (Osujieke et al., 2018). Basic soil information enables the creation of functional classification schemes for the management of soils in an ecosystem (Lekwa et al., 2004).

Soil characterization, soil mapping and land evaluation are very useful for achieving food security and environmental sustainability (Obasi et al., 2016). According to Stewart (1968) and van Diepen et al. (1991), land evaluation is the assessment of suitability of land for potential use in agriculture, forestry, engineering, hydrology, regional planning, and recreation, among others. Ogunkunle (2005) also described land evaluation as an applied classifi- cation system that assesses the capacity of soils for their variable uses, while aiming at deriving maximum benefits with minimum degradation. Soil characterization, on the other hand, is the measurement of soil properties by laboratory procedures and other standard methods using soil samples from pedons for the purposes of soil classification (Buol et al., 1997). It thus provides information on properties of soils that could be used in designing strategies for managing crop production, forests and grasslands (Ogunkunle, 2005). Characterization is also considered as a major step in classifying soils and understanding their properties and the environment in which they occur (Esu, 2005). The characteristics of a soil determine its suitability for crop production, and they are an agglomeration of the properties of each horizon in its profile (Olaniyan and Ogunwale, 2006).

Various approaches have been used to assess soil quality for sugarcane production. The methods include using algorithms to develop the Soil Management Assessment Framework (SMAF) (Cherubin et al., 2016) as well as use of the Agricultural Production Systems SiMulator (APSIM) model (Peng et al., 2020), Geographic Information System (GIS) and remote sensing (Subramani et al., 2017; Mubashir et al., 2017), the parametric approach (Neswati et al., 2016) and the

Please cite as: Ajala O.N., Adjadeh T.A., Olaniyan J.O., Isimikalu T.O., Nartey E.K. and James F.O. (2021). Characterization, classification and suitability evaluation of soils under sugarcane (Saccharum officinarum L.) cultivation at the Sugar Research Farm, University of Ilorin, Nigeria. Agro-Science, 20 (3), 14-23. DOI: https://dx.doi.org/10.4314/as.v20i3.3 
FAO's (1976) Framework for Land Evaluation guidelines used by Chartres (1981). The one to use would largely depend on resources available to the researcher.

Sugarcane is a warm-temperate and subtropical crop which requires warm, sunny, and moist climate and fertile, deep, and well aerated soils (Glyn, 2004). The crop cycle, growth and maturation are largely influenced by climatic conditions, especially moisture and heat. Dry sunny periods and low night temperatures are favourable for maturation and sugar accumulation (Glyn, 2004). The crop is sensitive to frost and hurricanes or typhoons (Purseglove, 1976; Willy, 2005). Each cultivar of sugarcane requires specific ecological conditions. The wild species of Saccharum officinarum L. thrives best under open field conditions; $S$. robustum grows best along riverbanks; $S$. spontaneum proliferates mainly in warm temperate regions and can tolerate a much wider range of conditions (Willy, 2005; Fábio et al., 2008). $S$. officinarum is essentially tropical, while $S$. barberi and $S$. sinense can be grown in subtropical and temperate countries (Willy, 2005). New hybrids have been developed which are adapted to a shorter growth cycle in subtropical areas (Willy, 2005). Unfavourable physical conditions such as soil compaction especially due to intense mechanization could be limiting to sugarcane cultivation (Fábio et al., 2008). Thus, for sustainable sugarcane production, it is very important to select sites with favourable soil fertility and physical properties. Site suitability studies guide the choice of crops to grow on soil units to maximize production per unit land (land use), labour and inputs (Thangasamy et al., 2005; Obasi et al., 2016; Mahesh et al., 2018).

The Sugar Research Institute of the University of Ilorin has about 15,000 ha of land dedicated to sugarcane production. However, soils of the Research Farm have not been characterized and classified. Thus, the objectives of this study were to characterize and classify the soils according to Soil Taxonomy and the World Reference Base for Soil Resources and evaluate the suitability of the soils for sustainable sugarcane production.

\section{MATERIALS AND METHODS}

\section{Study Sites}

This study was carried out at the Research Farm of the Sugar Research Institute, University of Ilorin (UNILORIN). The University of Ilorin Sugar Research Farm (USRF) is located along the banks of the Oyun River. There were two study sites, USRF1 and USRF2, which were about $2 \mathrm{~km}$ apart. The USRF1 site was 50 ha and situated along the road to the university. Four dominant soils (pedons I, II, III and IV) were identified at USRF1. The site was bounded by latitudes $8^{\circ} 28^{\prime} 15^{\prime \prime}$ and $8^{\circ} 29^{\prime} 45^{\prime \prime} \mathrm{N}$ and longitudes $4^{\circ} 39^{\prime} 44^{\prime \prime}$ and $4^{\circ} 40^{\prime}$ $03 "$ E. The soils were generally developed from a basement complex of rocks with dominant sandstone and quartzite. Pedons I and IV were located on a nearly flat to gently sloping (0-5\%) positions and on the middle slope to lower slope of a gently undulating landscape. Pedons II and III were located on nearly flat $(0-2 \%)$ positions and on an upper slope to middle slope of an almost flat landscape. There was only one dominant soil (pedon V) at the second site, USRF2, which was located near the Teaching and Research Farm of the University. USRF2 occupied an area of 15 ha and was bounded by latitudes $8^{\circ} 27^{\prime} 25.89^{\prime \prime} \mathrm{N}$ and $8^{\circ} 27^{\prime} 19.65^{\prime \prime} \mathrm{N}$, and longitudes $4^{\circ} 39^{\prime} 52.38^{\prime \prime} \mathrm{E}$ and $4^{\circ} 39^{\prime} 49.80^{\prime \prime}$ E. Pedon V was located on an almost flat $(0-2 \%)$ position and at the bottom slope of a landscape that was nearly flat to gently undulating. The Research Farm lies in the southern guinea savannah zone of Nigeria and with a climate characterized by wet and dry seasons. The dominant plant at both sites was Chromolaena odorata although USRF2 had a denser vegetation cover. Cultivation of sugarcane at USRF1 started in 2005 and predated that at USRF2 by about eight years. The temperature of Ilorin ranges from 25 to $30^{\circ} \mathrm{C}$ in the wet season and from 32 to $34^{\circ} \mathrm{C}$ in the dry season. Rainfall shows wide variability both temporally and spatially. On the average, annual rainfall ranges from 1000 to $1200 \mathrm{~mm}$, starting from April till October. The relative humidity in the wet season ranges between 75 to $80 \%$, while in the dry season, it falls to about $65 \%$ (Olaniran, 2002).

\section{Soil Sampling}

Reconnaissance surveys of the soils were carried out at both sites (USRF1 and USRF2). Then, the different soils at the two sites were identified and profile pits dug. Four pits were dug at USRF1 and one at USRF2 representing the different soils identified at the study sites. The profile pits were described, and soil samples collected from the genetic horizons according to the guidelines of FAO (1977; 2006) and Schoeneberger (2012). The morphological properties determined included soil colour according to the Munsell colour charts, soil structure, consistence, and drainage. The soil samples collected from the genetic horizons of the soil profiles were put into labelled polythene bags and taken to the laboratory for analysis.

\section{Laboratory Analyses}

The soil samples were air-dried for seven days, ground and sieved with a 2-mm sieve. Routine analyses were carried out using standard analytical procedures. Particle size distribution was determined with the hydrometer method (Gee and Or, 2002). Exchangeable bases $\left(\mathrm{Na}^{+}, \mathrm{Ca}^{2+}, \mathrm{Mg}^{2+}\right.$ and $\left.\mathrm{K}^{+}\right)$were extracted with ammonium acetate buffered at $\mathrm{pH} 7$. (Thomas, 1982) and their concentrations measured with the Atomic Absorption Spectrophotometer (AAS 210/211 Vap Buck Scientific). Exchangeable acidity was determined according to the method described by McLean (1982). Soil reaction ( $\mathrm{pH}$ ) was determined in a 1:2.5 soil-water ratio and measured with a pH meter (model-4070) (Thomas, 1996). 
Available phosphorus was determined using the Bray I method (Olsen and Sommers, 1982). Organic carbon content of the soils was determined according to the digestion method described by Nelson and Sommers (1996). Total Nitrogen was determined according to the micro-kjeldahl digestion technique (Bremner, 1996). Effective cation exchangeable capacity (ECEC) was determined by summation of the exchangeable bases $\left(\mathrm{Ca}^{2+} \mathrm{Mg}^{2+}\right.$ $\mathrm{K}^{+} \mathrm{Na}^{+}$) and exchangeable acidity. Calcium mole fraction was calculated as the fraction of exchangeable $\mathrm{Ca}^{2+}$ of ECEC. Percentage base saturation (BS) was determined as the percentage of the total exchangeable bases of the ECEC.

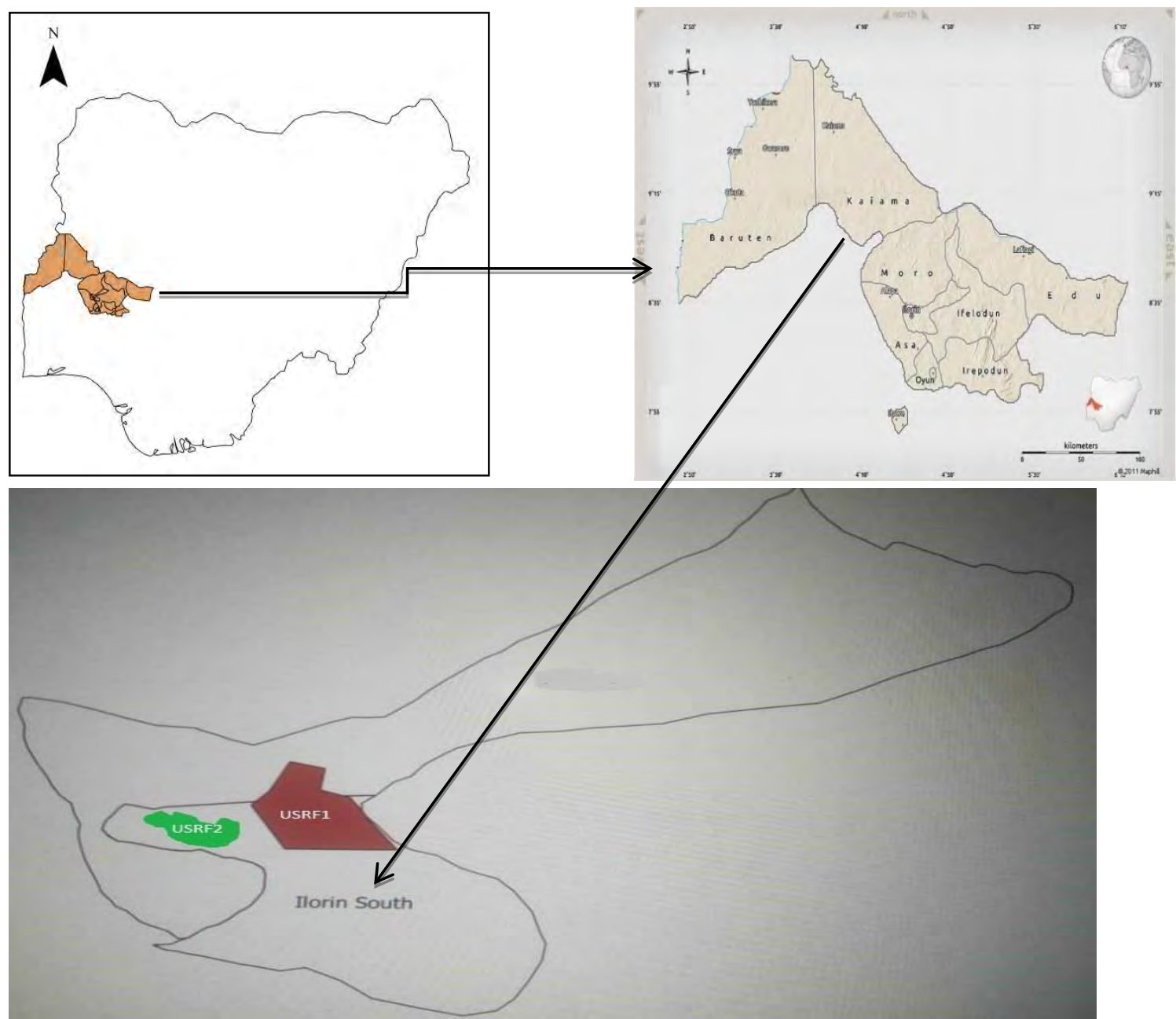

Figure 1a: Map of Nigeria showing the Kwara State and the study sites

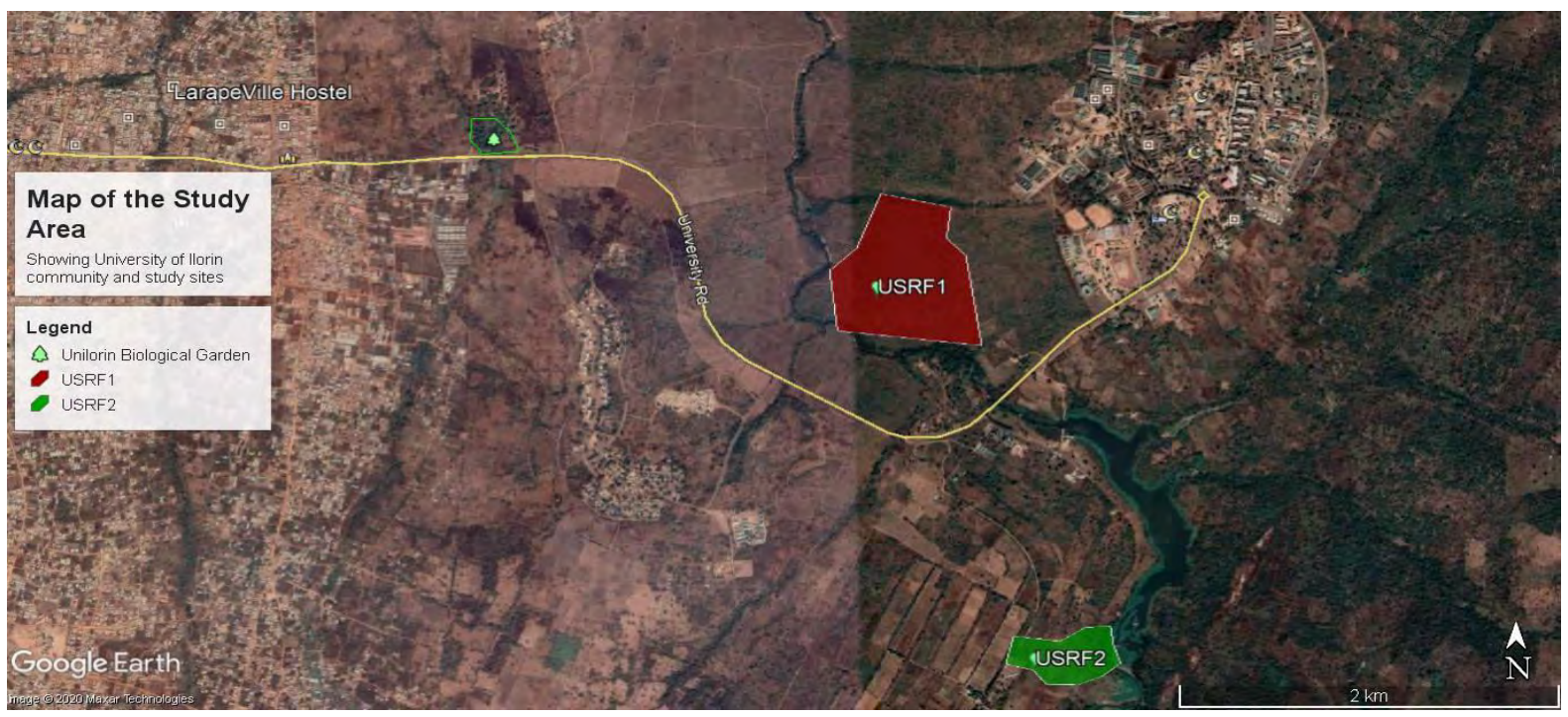

Figure 1b: Aerial photograph (Google Earth) of the University of Ilorin and locations of study sites 


\section{Classification of Soils}

The soils were classified according to Soil Taxonomy (Soil Survey Staff, 2014) and World Reference Base (WRB)for SoilResources(IUSS Working Group, 2015).

\section{Method of Soil and Land Suitability Evaluation}

The suitability of the lands (soils) for sugarcane cultivation was evaluated following the method described by Ogunkule (1993) and modified by Olaniyan and Ogunwale (2006). The method of evaluation followed the guidelines of Sys et al. (1991) on land evaluation. Each pedon was assigned a suitability class by matching its properties following the ratings of limiting characteristics. Based on the law of minimum, the most limiting characteristic in a group determined the class of pedon. The groups of qualities considered for evaluation were climate (c), topography (t), soil physical characteristics (s), wetness (w), chemical fertility (f), and salinity and alkalinity (n). However, calcium mole fraction was not included as a parameter under fertility index because sugarcane belongs to the grass family. Index of productivity (IP) was calculated for each pedon from the data generated using Equation 1 as described by Storie (1978) below:

$$
\mathrm{IP}=\mathrm{A} \times \mathrm{B} / 100 \times \mathrm{C} / 100 \ldots \mathrm{F} / 100 \ldots \ldots(1) ;
$$

where $\mathrm{A}$ is the overall lowest rating characteristic, and $\mathrm{B}, \mathrm{C} \ldots \mathrm{F}$ are the lowest rating characteristics for each land quality group. From this equation, the potential index of productivity (IPp) as well as the actual (current) index of productivity (IPc) was calculated. In determining IPp, length of rainy season was not included in the climate (c) group and calcium mole fraction, available phosphorus $(\mathrm{P})$ and organic matter were not included in the fertility (f) group. They were, however, included in the calculation of IPc. In all, the suitability ratings viz highly suitable (S1), moderately suitable (S2), marginally suitable (S3) and currently unsuitable $(\mathrm{N})$ were directly equivalent to IP values of $75-100 \%, 50-74 \%, 25-$ $49 \%$, and $0-24 \%$, respectively (Olaniyan and Ogunwale, 2006). This method has been used to determine soil suitability for various crops including sugarcane (Neswati et al., 2016), cashew (Olaniyan and Ogunwale., 2006), cowpea (Ogunwale et al., 2009), cocoa (Ajiboye et al., 2015), and rice (Ajiboye et al., 2011; Osinuga et al., 2020).

\section{RESULTS AND DISCUSSION}

Morphological and Physical Properties of the Soils The morphological and physical properties of the soils are presented in Table 1. At USRF1, the depth of the pedons ranged from 65 to $120 \mathrm{~cm}$. Pedons II (80 $\mathrm{cm}$ deep) and III (65 cm deep) were relatively shallow due to the presence of subsurface petroplinthite (pisoplinthite under WRB). Pedon V at USRF2 was $130 \mathrm{~cm}$ deep. Although soil depth $>1 \mathrm{~m}$ is ideal (Schulze et al., 1997), all the soils were generally deep enough for sugarcane cultivation. However, the depths of pedons II and III could be limiting due to possible water logging and runoff especially under heavy rainfall or flood irrigation conditions.
The colour of the soils varied from light (5YR3/1) to strong brown $(7.5 \mathrm{YR} 5 / 6)$ in pedon I; weak brown (7.5.YR4/4) to yellowish red (5YR4/6) in pedon II; strong brown $7(.5 \mathrm{YR} 3 / 4)$ to red $(2.5 \mathrm{YR} 3 / 4)$ in pedon III; light (5YR3/1) to strong brown $(7.5 \mathrm{YR} 5 / 6)$ in pedon IV and dark brown (7.5YR5/2) through greyish dark brown (5YR5/6) to greyish brown $(2.5 \mathrm{YR} 4 / 6)$ in pedon V. The dark brown surface soil of pedon $\mathrm{V}$ could be due to dominant organic matter decomposition as had been reported by Okenmuo et al. (2020). Also, the greyish colour of the subsurface and subsoil horizons of pedon $\mathrm{V}$ was probably due to poordrainage and more hypoxic conditions at USRF2. Osujieke et al. (2018) had attributed differences in the colour of some soils in a comparable environment in northeastern Nigeria to differences in drainage.

The soils contained high amounts of sand: USRF1 (71.41-86.74\%) and USRF2 (49.52-79.52\%). The very high sand content of the soils especially at USRF1 could be attributed to their sandstone and quartzite parent materials. The clay content of the soils from USRF1 ranged from 10.26 to $22.69 \%$ while that of the soil from USRF2 ranged from 20.19 to $36.46 \%$. The soils contained very small amounts of silt (USRF1: 3-6\%; USRF2: 12-16\%). Thus, while the soils from USRF1 contained predominantly high amounts of sand, the soil from USRF2 contained relatively more silt and clay fractions. With increasing clay content with depth, pedon $\mathrm{V}$ showed an argillic horizon. Pedons I and IV were loamy sand throughout their profiles while pedons II and III were loamy sand in the A-horizon but gravelly loamy sand in their subsurface soil. Pedon V was sandy loam in the surface soil, sandy clay loam in the subsurface soil and clay loam in the subsoil. The higher clay content of the subsurface and subsoil horizons of pedon $\mathrm{V}$ could be attributed to illuviation which resulted in the formation of an argillic horizon. Nuga et al. (2008) had reported similar properties for soils on a catena at Ikwuano, Abia State, Nigeria. Due to its higher clay content, pedon V (USRF2) would have higher water holding capacity and a different irrigation regime compared to the soils at USRF1(Kramer and Boyer, 1995; Brady and Weil, 2008). Although clay loams are reportedto be the best for sugarcane production (Mubashir et al., 2017), soils with other textures could be used with some management.

The percentage gravel content of the soils varied from 16.80 to $29.32 \%$ in USRF1 and 5.31 to $7.86 \%$ in USRF 2 . Pedons II and III had impervious layers at depths of 80 and $65 \mathrm{~cm}$ respectively. The high gravel content of the subsurface soils of pedons II and III was due to the large amounts of ironstone concretions lying above the petroplinthite layers in these soils. It is noteworthy to indicate that the name Ilorin derived from "abundance of ironstone concretions in the land (soil)" in Yoruba language. The high sand content of the soils at USRF1 indicates that they would have low water 
holding capacity (Kramer and Boyer, 1995; Brady and Weil, 2008) and may be prone to erosion (Salako, 2003). These soils may also be more susceptible to leaching of nutrients from the surface horizons than the soil from USRF2 (pedon V).

Apart from the subsurface horizons of pedons II and III which had granular structure due to the high amounts of gravels they contained, all the soils at USRF1 were massive in structure. Pedon V, on the other hand, had sub-angular blocky structure in all the horizons which makes the soil more agronomically desirable (Hillel, 2004). The higher clay and organic carbon contents (Table 2) of pedon $\mathrm{V}$ might have in part contributed to the sub-angular blocky structure of all the horizons of the profile (Hillel, 2004). Soil structure is one of the most important properties affecting crop production because it determines the depth to which roots can penetrate and proliferate, the amount of water that can be stored and the movement of air, water, and soil fauna (Hermavan and Cameron, 1993; Langmaack, 1999). The consistence of the soils from USRF1 was friable while that of the soil from
USRF2 was firm. The horizons of the soils from USRF1 were well-drained. On the other hand, the $\mathrm{Ap}$ and Bt1 -horizons of pedon $\mathrm{V}$ were imperfectly drained while the $\mathrm{Bt} 2$ horizon was poorly drained.

\section{Chemical Properties of the Soils}

The chemical properties of the soils are presented in Table 2. The $\mathrm{pH}\left(\mathrm{H}_{2} \mathrm{O}\right)$ of the USRF1 soils ranged from 5.3 in the Ap horizon of pedon II to 6.2 in the AB horizon of pedon III. The $\mathrm{pH}\left(\mathrm{H}_{2} \mathrm{O}\right)$ of pedon $\mathrm{V}$ (USRF2) on the other hand, ranged from 6.7 in the Ap horizon to 7.5 in the $\mathrm{Bt}_{2}$ horizon. Thus, while the $\mathrm{pH}$ of the USRF1 soils was moderately acid, that of the USRF2 soil was slightly acid to slightly alkaline. The $\mathrm{pH}$ range of 5.3-7.5 obtained in this study is likely to support sugarcane production. Mubashir et al. (2017) had reported that a $\mathrm{pH}$ range of 6.5 to 8.5 was the most suitable for sugarcane cultivation in the Bijnor District of India. However, for crop growth in general, total acidity (i.e., sum of exchangeable aluminium $\left(\mathrm{Al}^{3+}\right)$ and hydrogen $\left(\mathrm{H}^{+}\right)$should range from 0.2 to 10.4 cmolc $\mathrm{kg}^{-1}$ to avoid aluminum toxicity (Ogunkunle, 2005).

Table 1: Morphological and physical properties of the soils

\begin{tabular}{|c|c|c|c|c|c|c|c|c|c|c|c|}
\hline Pedon & $\begin{array}{l}\text { Hori- } \\
\text { zon }\end{array}$ & $\begin{array}{l}\text { Depth } \\
(\mathrm{cm})\end{array}$ & Colour (moist) & Sand & $\begin{array}{l}\text { Silt } \\
(\%)\end{array}$ & Clay & $\begin{array}{c}\text { Gravel } \\
(\%)\end{array}$ & $\begin{array}{c}\text { Textural } \\
\text { class }\end{array}$ & Structure & $\begin{array}{c}\text { Consistence } \\
\text { (moist) }\end{array}$ & Drainage \\
\hline \multirow[t]{2}{*}{ I } & Ap & $0-43$ & $\begin{array}{l}\text { Light brown } \\
5 Y R 3 / 1\end{array}$ & 84.48 & 5.00 & 10.52 & 18.29 & LS & massive & Friable & V \\
\hline & $\mathrm{AB}$ & $43-120$ & $\begin{array}{l}\text { Strong brown } \\
\text { 7.5.YR5/6 }\end{array}$ & 85.58 & 4.00 & 10.42 & 21.05 & LS & massive & Friable & V \\
\hline \multirow[t]{2}{*}{ II } & Ap & $0-25$ & $\begin{array}{l}\text { Weak brown } \\
7.5 . \text { YR4/4 }\end{array}$ & 83.56 & 5.00 & 11.44 & 21.25 & LS & massive & Friable & V \\
\hline & $\mathrm{ABdc}$ & $25-80$ & $\begin{array}{l}\text { Yellowish red } \\
\text { 5YR4/6 }\end{array}$ & 86.74 & 3.00 & 10.26 & 28.94 & GLS & granular & Friable & V \\
\hline \multirow[t]{2}{*}{ III } & Ap & $0-15$ & $\begin{array}{c}\text { Strong brown } \\
7.5 \mathrm{YR} 3 / 4\end{array}$ & 71.41 & 5.00 & 22.69 & 17.50 & LS & massive & Friable & V \\
\hline & $\mathrm{ABdc}$ & $15-65$ & Red 2.5 YR3/4 & 72.42 & 6.00 & 21.58 & 29.32 & GLS & granular & Friable & V \\
\hline \multirow[t]{2}{*}{ IV } & Ap & $0-50$ & $\begin{array}{l}\text { Light brown } \\
5 \text { YR3/1 }\end{array}$ & 82.54 & 5.00 & 12.46 & 16.80 & LS & massive & Friable & V \\
\hline & $\mathrm{AB}$ & $50-90$ & $\begin{array}{l}\text { Strong brown } \\
7.5 \mathrm{YR} 5 / 6\end{array}$ & 80.63 & 6.00 & 13.37 & 18.86 & LS & massive & Friable & V \\
\hline \multirow[t]{3}{*}{ V } & $\mathrm{Ap}$ & $0-42$ & $\begin{array}{c}\text { Dark brown } \\
7.5 \mathrm{YR} 5 / 2\end{array}$ & 67.80 & 12.00 & 20.19 & 7.86 & SL & sub-ab & Firm & IV \\
\hline & Bt1 & $42-74$ & $\begin{array}{c}\text { Greyish dark } \\
\text { brown 5YR 5/6 }\end{array}$ & 59.52 & 16.00 & 24.48 & 6.19 & SCL & sub-ab & Firm & IV \\
\hline & Bt2 & $74-130$ & $\begin{array}{c}\text { Greyish brown } \\
2.5 \text { YR4/6 }\end{array}$ & 49.52 & 14.00 & 36.46 & 5.31 & CL & sub-ab & Firm & II \\
\hline
\end{tabular}

LS is loamy sand, SCL is sandy clay loam, CL is clay loam, GLS is gravelly loamy sand, sub-ab is sub-angular blocky,

II is poorly drained, IV is imperfectly drained, $\mathrm{V}$ is well drained

Table 2: Chemical properties of the soils

\begin{tabular}{|c|c|c|c|c|c|c|c|c|c|c|c|c|c|}
\hline \multirow[b]{2}{*}{ Pedon } & \multirow{2}{*}{$\begin{array}{l}\text { Hori- } \\
\text { zon }\end{array}$} & \multirow[b]{2}{*}{$\mathrm{pH}$} & \multicolumn{4}{|c|}{ Exchangeable bases } & \multirow{2}{*}{$\begin{array}{c}\text { Exchangeable } \\
\text { acidity } \\
\left(\mathrm{cmol}_{\mathrm{c}} \mathrm{kg}^{-1}\right)\end{array}$} & \multirow{2}{*}{$\begin{array}{c}\text { ECEC } \\
\left(\mathrm{cmol}_{\mathrm{c}} \mathrm{kg}^{-1}\right)\end{array}$} & \multirow{2}{*}{$\begin{array}{l}\mathrm{BS} \\
(\%)\end{array}$} & \multirow{2}{*}{$\begin{array}{l}\mathrm{Ca} \\
\text { mole } \\
\text { fratn }\end{array}$} & \multirow{2}{*}{$\begin{array}{c}\text { Organic } \\
\text { carbon } \\
\left(\mathrm{g} \mathrm{kg}^{-1}\right)\end{array}$} & \multirow{2}{*}{$\begin{array}{c}\text { Total } \\
\text { nitrogen } \\
\left(\mathrm{g} \mathrm{kg}^{-1}\right)\end{array}$} & \multirow{2}{*}{$\begin{array}{c}\text { Available } \\
\text { phosphorus } \\
\mathrm{mg} \mathrm{kg}^{-1}\end{array}$} \\
\hline & & & $\mathrm{Ca}^{2+}$ & $\begin{array}{c}\mathrm{Mg}^{2+} \\
\left(\mathrm{cmol}_{\mathrm{c}}\right.\end{array}$ & $\begin{array}{c}\mathrm{K}^{+} \\
\left.\mathrm{kg}^{-1}\right)\end{array}$ & $\mathrm{Na}^{+}$ & & & & & & & \\
\hline \multirow[t]{2}{*}{ I } & $\mathrm{Ap}$ & 5.50 & 1.40 & 0.60 & 0.50 & 0.06 & 0.83 & 3.39 & 75.50 & 0.41 & 0.82 & 0.05 & 10.40 \\
\hline & $\mathrm{AB}$ & 5.70 & 0.80 & 0.30 & 0.30 & 0.04 & 0.85 & 2.29 & 62.90 & 0.35 & 0.71 & 0.05 & 6.18 \\
\hline \multirow[t]{2}{*}{ II } & Ap & 5.30 & 1.80 & 0.70 & 0.50 & 0.04 & 1.25 & 4.29 & 70.80 & 0.42 & 0.92 & 0.06 & 7.72 \\
\hline & $\mathrm{ABdc}$ & 5.60 & 1.30 & 0.50 & 0.40 & 0.02 & 1.46 & 3.68 & 60.30 & 0.35 & 0.74 & 0.06 & 5.34 \\
\hline \multirow[t]{2}{*}{ III } & Ap & 5.80 & 1.50 & 0.90 & 0.80 & 0.15 & 0.94 & 4.29 & 78.10 & 0.35 & 0.86 & 0.04 & 8.37 \\
\hline & $\mathrm{ABdc}$ & 6.20 & 0.70 & 0.60 & 0.50 & 0.21 & 1.11 & 3.12 & 64.40 & 0.22 & 0.82 & 0.04 & 6.13 \\
\hline \multirow[t]{2}{*}{ IV } & Ap & 5.90 & 1.60 & 0.70 & 0.50 & 0.20 & 1.04 & 4.04 & 74.30 & 0.40 & 0.95 & 0.06 & 5.21 \\
\hline & $\mathrm{AB}$ & 6.10 & 1.90 & 0.50 & 0.80 & 0.21 & 0.54 & 3.95 & 86.30 & 0.48 & 0.83 & 0.05 & 6.20 \\
\hline \multirow[t]{3}{*}{ V } & Ap & 6.70 & 3.60 & 1.30 & 1.00 & 0.21 & 0.88 & 6.99 & 87.40 & 0.52 & 15.40 & 1.03 & 8.12 \\
\hline & Bt1 & 7.30 & 5.60 & 0.90 & 0.70 & 0.31 & 1.76 & 9.27 & 81.00 & 0.60 & 10.60 & 0.92 & 6.20 \\
\hline & $\mathrm{Bt} 2$ & 7.50 & 2.80 & 0.60 & 0.40 & 0.26 & 1.84 & 5.90 & 68.80 & 0.47 & 8.80 & 0.90 & 3.21 \\
\hline
\end{tabular}

BS is base saturation, ECEC is effective cation exchangeable capacity, Ca mole fratn is fraction of exchangeable Ca and ECEC. 
The soils were not likely to be saline judging from their $\mathrm{pH}$ and the low levels of exchangeable sodium. The exchangeable sodium percentage (ESP) of the soils ranged from 0.54 to $6.73 \%$ (not shown) which was less than the $15 \%$ critical level for sodic soils (US Salinity Laboratory Staff, 1954). Hence, none of the soils was likely to have salt problems under rainfed conditions. Among the basic cations, $\mathrm{Ca}^{2+}$ was the highest in all the soils. Its content in USRF1 ranged from 0.7 to $1.9 \mathrm{cmol}_{\mathrm{c}} \mathrm{kg}^{-1}$ whereas in pedon $\mathrm{V}$ (USRF 2) it was 2.8 to $5.6 \mathrm{cmol}_{\mathrm{c}} \mathrm{kg}^{-1}$. Pedon $\mathrm{V}$ also contained higher amounts of $\mathrm{Mg}^{2+}$ (0.6-1.3 $\left.\mathrm{cmol}_{\mathrm{c}} \mathrm{kg}^{-1}\right), \mathrm{K}^{+}\left(0.4-1.0 \mathrm{cmol}_{\mathrm{c}} \mathrm{kg}^{-1}\right)$ and $\mathrm{Na}^{+}$(0.21-0.31 cmolc $\left.\mathrm{kg}^{-1}\right)$ than the soils from USRF1. The levels of $\mathrm{Mg}^{2+}, \mathrm{K}^{+}$and $\mathrm{Na}^{+}$in the URSF1 soils were $0.3-0.9,0.3-0.8$ and $0.02-0.21$ $\mathrm{cmol}_{\mathrm{c}} \mathrm{kg}^{-1}$, respectively. Although none of the exchangeable cations would be limiting in the soils for sugarcane production (FPDD, 1989), the levels of $\mathrm{K}$ may have to be augmented especially for a second season cultivation (Oliveira et al., 2016).

All the soils had low levels of ECEC indicating that their exchange complex was likely to be dominated by kaolinite. This inference agrees with the report of Igwe et al. (1999), which revealed that some soils at Southeastern Nigeria with low CEC were dominated by kaolinite. The ECEC of the surface and the sub-soil horizons of the USRF1 soils ranged from 3.39 to $4.29 \mathrm{cmolc} \mathrm{kg}^{-1}$ and 2.29 to $3.95 \mathrm{cmolc} \mathrm{kg}^{-1}$, respectively. In pedon V (USRF2), ECEC was $6.99 \mathrm{cmolc} \mathrm{kg}^{-1}$ in the surface soil, increased to $9.27 \mathrm{cmolc} \mathrm{kg}^{-1}$ in the Bt1 horizon and decreased to $5.9 \mathrm{cmolc} \mathrm{kg}^{-1}$ in the $\mathrm{Bt} 2$ horizon. These ECEC levels of the soils were generally adequate for sugarcane production (FPDD, 1989). With higher organic $\mathrm{C}$ and clay contents of pedon $\mathrm{V}$, it is expected that the soil would have higher ECEC compared to the soils from USRF1. Similar positive relationships of organic matter and clay contents with CEC (ECEC) had been reported by Parfitt et al. (1995), Obalum et al. (2013), and Dai et al. (2018). However, the effect of organic matter and clay contents on the variability of ECEC with soil depth at both study sites is not clear. Base saturation ranged from 70.8 to $78.1 \%$ in the surface soils and 60.3 to $86.3 \%$ in the sub-surface soils of USRF 1 . In pedon $\mathrm{V}$, base saturation ranged from $87.4 \%$ in the surface soil to $68.8 \%$ in the sub-surface soil. Generally, base saturation of the soils, rated as moderate to high, decreased with increasing depth.

The organic carbon content of the soils from USRF1 was very low $\left(<0.96 \mathrm{~g} \mathrm{~kg}^{-1}\right)$. On the contrary, pedon V (USRF2) had a higher organic C content (8.8-15.4 $\mathrm{g} \mathrm{kg}^{-1}$ ), about ten to sixteen folds higher than the levels in the USRF1 soils. The higher organic $\mathrm{C}$ content of pedon $\mathrm{V}$ was likely to be due to the denser vegetation cover and the relatively shorter period the soils at USRF2 have put under sugarcane cultivation. Also, pedon $\mathrm{V}$ had a more favourable soil environment for organic $\mathrm{C}$ accretion due its higher clay content. The very low levels of organic $\mathrm{C}$ content and the high sand content of the soils from USRF1 could predispose them to erosion and nutrients loss. The soils from USRF1 contained very small amounts of total $\mathrm{N}$ which ranged from 0.040 to $0.063 \mathrm{~g} \mathrm{~kg}^{-1}$. Pedon $\mathrm{V}$ from USRF2, on the other hand, contained about ten folds higher levels of total N (0.88-1.03 $\left.\mathrm{g} \mathrm{kg}^{-1}\right)$ than the levels in the soils from USRF1. In all the soils, the level of total $\mathrm{N}$ decreased with soil depth in direct relationship with organic $\mathrm{C}$ content of the soils. Sugarcane, a member of the grass family, requires substantial amount of nitrogen for its development (Kingston, 2014; Oliveira et al., 2016). Thus, the total $\mathrm{N}$ content of the soils from USRF1 would be inadequate to support sugarcane production. Presently, the fertilizer being applied to sugarcane at the study sites is NPK (15-15-15) at a rate of $200 \mathrm{~kg}$ per ha. This level of $\mathrm{N}\left(30 \mathrm{~kg} \mathrm{ha}^{-1}\right)$ appears to be low compared to rates recommended for sugarcane elsewhere which ranged from 34 to $400 \mathrm{~kg} \mathrm{ha}^{-1}$ (Saleem et al., 2012; Mwasinga, 2018; McCray, 2019; Gravois, 2021; Haifa Group, 2021). On the other hand, the total $\mathrm{N}$ contents of pedon $\mathrm{V}$ and the $200 \mathrm{~kg} \mathrm{ha}^{-1}$ NPK 15-15-15 may be adequate for sugarcane cultivation at USRF2. Nevertheless, further studies need to be conducted to determine recommended rates of $\mathrm{N}$ to apply to the soils at both USRF1 and USRF2.

The available $P$ levels in the soils from USRF1 ranged from 5.21 to 10.4 and 5.34 to $6.20 \mathrm{mg} \mathrm{kg}^{-1}$ in the surface and sub-soil horizons, respectively. In pedon $\mathrm{V}$ (USRF2), the available $\mathrm{P}$ content ranged from $8.12 \mathrm{mg} \mathrm{kg}^{-1}$ in the Ap horizon to $3.21 \mathrm{mg} \mathrm{kg}^{-1}$ in the Bt2 horizon. Comparably, low levels of available $\mathrm{P}$ were reported for some concretionary soils in Nigeria (Sobulo, 1982) and Ghana (Oteng and Acquaye, 1971; Kanabo et al., 1978; Nyamekye, 1987; Abekoe, 1989). Phosphorus deficiency in tropical soils with low activity clays has been attributed to high $\mathrm{P}$ adsorption (Sanchez and Salinas, 1981; Abekoe and Sahrawat, 2001). Phosphorus is a major plant nutrient responsible for root development so the soils would have to be augmented with $\mathrm{P}$ for productive cultivation of sugarcane. The $30 \mathrm{~kg} \mathrm{ha}^{-1}$ $\mathrm{P}$ (from the $200 \mathrm{~kg} \mathrm{ha}^{-1}$ NPK (15-15-15) being applied at the study sites) would not be adequate for optimum sugarcane production. In a sugarcane response study on clay soils, Mistry et al. (2018) reported that $150 \mathrm{~kg} \mathrm{ha}^{-1}$ of $\mathrm{P}$ gave the best result. Gravois (2021) has recommended $50.4 \mathrm{~kg} \mathrm{ha}^{-1} \mathrm{P}$ for soils with very low P levels and $0 \mathrm{~kg} \mathrm{ha}^{-1}$ for soils with low to high levels of $\mathrm{P}$ for sugarcane production. Just like $\mathrm{N}$, further study must be conducted to determine recommended rates of $\mathrm{P}$ to apply to the soils at both USRF1 and USRF2.

Classification of the Soils Using the Soil Taxonomy The study sites experience about six months of dry season so the upper parts of the moisture control section (upper $50 \mathrm{~cm}$ of the soils) would be dry for 
more than 90 cumulative days in most years. The soils were therefore likely to have ustic soil moisture regime. The soils were iso-hyperthermic because their mean annual temperature was more than $22^{\circ} \mathrm{C}$ and with a mean hot season and cool season soil temperature differing by less than $5^{\circ} \mathrm{C}$ at more than $50 \mathrm{~cm}$ depth of the soil.

At the order categorical level, all the pedons from USRF1 were classified as Inceptisols while pedon V from USRF2 was classified as an Alfisol (Soil Survey Staff, 2014). Based on their moisture regime, the USRF1 soils were classified as Ustepts at the sub-order level. At the great group level, all the soils from USRF1 were classified as Haplustepts. At the subgroup level, pedons I and IV were classified as Typic Haplustepts while pedons II and III were classified as Lithic Haplustepts due to the presence of a lithic contact created by the subsoil plinthite in these soils. Pedon V from USRF2 was classified as an Alfisol because of its argillic horizon and as an Ustalf at the suborder level because of its ustic moisture regime. At the great group level, it was classified as a Haplustalf and at the subgroup level, as a Kanhaplic Haplustalf due to the low level of ECEC $\left(<10 \mathrm{cmol} \mathrm{kg}^{-1}\right)$.

\section{Classification of the Soils According to World Reference Base for Soil Resources}

Under the Reference Soil Groups (RSGs), pedons I and IV were classified as Regosols (IUSS Working Group WRB, 2015). Although the two soils were loamy sand, they were not classified as Arenosols because they had coarse fragments (sand + gravel) far in excess of $40 \%$ by volume. Though percentage coarse fragment on volume basis was not determined, on weight basis the soils contained $>80 \%$ coarse fragments. Moreover, their $<20 \%$ clay + silt content (on weight basis) could not constitute more than $60 \%$ of their soil volume. Thus, the two soils could not be classified as Arenosols. They were given the principal qualifier eutric because of their effective base saturation was $>50 \%$ in all horizons. They were given arenic supplementary qualifier because of their loamy sand texture. The two soils were therefore classified as Eutric Regosols (Arenic).

Pedons II and III keyed out as Cambisols because they had a pisoplinthic horizon at a depth $<100 \mathrm{~cm}$ from the soil surface. The two pedons were given Endo-Pisoplinthic principal qualifier because of their subsurface pisoplinthic layer $(>50 \mathrm{~cm}$ from the soil surface). The two pedons were given arenic supplementary qualifier because of their loamy sand texture. Pedons II and III were therefore classified as Endo-Pisoplinthic Cambisols (Arenic). Pedon V keyed out as a Lixisol because it had an argic horizon at a depth $<100 \mathrm{~cm}$ from the soil surface and CEC $\left(\right.$ ECEC) $<24 \mathrm{cmolc} \mathrm{kg}^{-1}$. Due to its subsurface gleyic properties, the soil was given gleyic principal qualifier. It was given loamic supplementary qualifier because of its loamy texture. Pedon V was therefore classified as a gleyic lixisol (loamic).

\section{Suitability Ratings}

The climate of the study sites was favourable for sugarcane cultivation. A mean annual temperature $\left(30-31^{\circ} \mathrm{C}\right)$ was suitable for sugarcane cultivation (Blume, 1985; Tarimo and Takamura, 1998; Cornland et al., 2001). A mean annual rainfall of $1000-1200 \mathrm{~mm}$ at the study sites is very close to the recommended 1200-1500 $\mathrm{mm}$ for sugarcane cultivation (Blume, 1985; Tarimo and Takamura, 1998; FAO AGL, 2002). However, a rainy season of about seven months duration in Ilorin is not adequate so supplementary water supply would be required for optimal sugarcane production. Length of rainy season was therefore not included in the computation of potential suitability. In the case of current aggregate suitability, length of rainy season was the most limiting climatic characteristic. Relative humidity levels of 75 to $80 \%$ in the rainy season and $65 \%$ during dry season recorded at the study sites were adequate for sugarcane cultivation (Yates, 1977; Schulze, 1997).

Land requirement for sugarcane production, suitability ratings of the various land characteristics as well as their aggregate ratings (potential and actual) are presented in Tables 3 and 4 . Pedon V from USRF2 (total area of $15 \mathrm{ha}$ ) was rated best (highly suitable, $85.25 \%$ ) in terms of potential aggregate suitability. Pedons I and IV whose land coverage were 12 and 16 ha, respectively followed with a suitability of $64.53 \%$ (i.e., moderately suitable). Pedon II (land area of 15 ha) had a suitability of $47.40 \%$ (marginally suitable). Pedon III (7 ha of land area) had a suitability of $35.62 \%$ (unsuitable for sugarcane cultivation). Topography of both sites ( $<5 \%$ slope) was favourable for sugarcane cultivation (Griffee, 2000). However, while the USRF1 soils were well drained, the USRF2 soils were poorly drained. Shallow depth and high gravel content were the main limitations of pedon III. Water and nutrients should be applied in split doses to the soils of pedons I, II and IV to minimize leaching and runoff. The aggregate suitability ratings of the soils from USRF1 were very low due to their low fertility status and sandy texture. The high sand content of these soils would predispose them to excessive leaching of nutrients and poor moisture retention. The soils from USRF1 were therefore rated as unsuitable for sugarcane production. They could, however, be made suitable through fertilizer application, especially organic amendments, and good residue management practices. Also, supplementary water supply through provision of appropriate irrigation would improve the suitability of the soils from USRF1. Pedon V, on the other hand, was rated suitable for sugarcane production due its better fertility status and more favourable texture. However, drainage at USRF2 would have to be improved for optimal sugarcane production at the site. 
Characterization, Classification and Suitability Evaluation of Soils under Sugarcane at Ilorin, Nigeria21

Table 3: Land requirements for suitability classes for sugarcane cultivation ${ }^{\dagger}$

\begin{tabular}{|c|c|c|c|c|c|c|}
\hline \multirow[b]{2}{*}{ Land quality } & \multicolumn{6}{|c|}{ Suitability classes } \\
\hline & $\begin{array}{l}\text { Highly } \\
\text { suitable (S1) } \\
(85-95 \%) \\
\end{array}$ & $\begin{array}{l}\text { Moderately } \\
\text { suitable (S2) } \\
(60-85 \%) \\
\end{array}$ & $\begin{array}{l}\text { Sub-moderately } \\
\text { suitable }\left(\mathrm{S} 2_{1}\right) \\
(40-60 \%)\end{array}$ & $\begin{array}{l}\text { Marginally } \\
\text { suitable (S3) } \\
(25-40 \%)\end{array}$ & $\begin{array}{l}\text { Currently } \\
\text { unsuitable (N1) } \\
(25-40)\end{array}$ & $\begin{array}{l}\text { Permanently } \\
\text { unsuitable (N2) } \\
(0-25)\end{array}$ \\
\hline \multicolumn{7}{|c|}{ 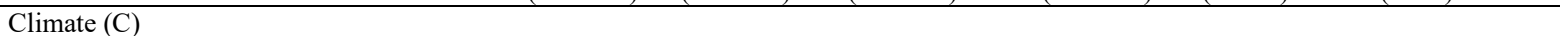 } \\
\hline Annual rainfall (mm) & $>1200$ & $1000-1200$ & $800-1000$ & $600-800$ & - & $>600$ \\
\hline Monthly rainfall (mm) & $>5$ & $4-5$ & $3-4$ & $2-3$ & - & $>2$ \\
\hline Mean annual maximum temperature $\left({ }^{\circ} \mathrm{C}\right)$ & $>29$ & $29-27$ & $24-27$ & $22-24$ & - & $>22$ \\
\hline Average daily minimum temperature $\left({ }^{\circ} \mathrm{C}\right)$ & $>20$ & $18-20$ & $16-18$ & $14-16$ & - & $>14$ \\
\hline Mean annual temperature $\left({ }^{\circ} \mathrm{C}\right)$ & $>25$ & $22-25$ & $20-22$ & $18-20$ & - & $>18$ \\
\hline Relative humidity (\%) & $>75$ & $70-75$ & $65-70$ & $60-65$ & - & $>60$ \\
\hline \multicolumn{7}{|l|}{ Topography (T) } \\
\hline Slope $(\%)$ & $0-4$ & $4-8$ & $8-12$ & $12-16$ & $>16$ & - \\
\hline Drainage & I & I & II & III & IV & $\mathrm{V}$ \\
\hline \multicolumn{7}{|l|}{ Soil physical properties (S) } \\
\hline Textural classes & LS & SL & SCL & $\mathrm{SC}$ & any & $\mathrm{CL}, \mathrm{C}$ \\
\hline Coarse fragment vol. $\% 0-30 \mathrm{~cm}$ & $3-10$ & $10-15$ & $15-35$ & $35-55$ & - & $>55$ \\
\hline Structure & Crumbs & Crumb & Sub-ab. & Sub-ab. & Colum. & Colum. \\
\hline Depth $(\mathrm{cm})$ & $>100$ & $90-100$ & $50-90$ & $25-50$ & $15-25$ & $5-15$ \\
\hline Soil chemical (fertility) properties $(\mathrm{F})$ & $>70$ & $60-70$ & $40-60$ & $20-40$ & $<20$ & $<10$ \\
\hline Base saturation & $>70$ & $60-70$ & $40-60$ & $20-40$ & - & 0 \\
\hline $\mathrm{pH}$ & $>6.0-6.5$ & $6.0-7.0$ & $5.5-6.0$ & $5.0-5.5$ & $4.5-5.0$ & $<4.5->7.5$ \\
\hline Organic carbon $(\%) 0-30 \mathrm{~cm}$ & $>1.5-2.0$ & $1.5-2.0$ & $1.25-1.5$ & $1.0-1.25$ & $<1.0$ & $<1.0$ \\
\hline Ca. mole fraction & $0.8-0.9$ & $0.7-0.8$ & $0.6-0.7$ & $0.4-0.6$ & $0.2-0.4$ & $<0.2$ \\
\hline Available phosphorus $\mathrm{m} \mathrm{kg}^{-1} 0-30 \mathrm{~cm}$ & $>20$ & $16-20$ & $12-16$ & $8-12$ & $4-8$ & $<4$ \\
\hline Salinity and alkalinity $(\mathrm{dS} / \mathrm{m})(\mathrm{n})$ & $<1$ & $1-2$ & $2-3$ & $3-4$ & $4-8$ & $>8$ \\
\hline \multicolumn{7}{|c|}{$\begin{array}{l}\text { SL - sandy loam, SCL - sandy clay loam, SC - sandy clay, CL - clay loam, C - clay; sub-ab - sub-angular blocky, colum. - columnar; I - well drained, } \\
\text { II - moderately drained, III - fairly drained, IV - imperfectly drained, V - poorly drained; †Modified from FAO (2007) and Ogunwale et al. (2006) }\end{array}$} \\
\hline \multicolumn{7}{|l|}{ Table 4: Suitability classes of the soils } \\
\hline Characterization & Pedon I & \multicolumn{2}{|c|}{ Pedon II } & Pedon III & Pedon IV & Pedon V \\
\hline Annual rainfall & S1 (95) & \multicolumn{2}{|l|}{ S1 (95) } & S1 (95) & S1 (95) & S1 (95) \\
\hline Length of rainy season & S2 (70) & \multicolumn{2}{|l|}{ S2 (70) } & S2 (70) & $\mathrm{S} 2(70)$ & S2 (70) \\
\hline Mean annual maximum temperature & S1 (100) & \multicolumn{2}{|c|}{ S1 (100) } & S1 (100) & $\mathrm{S} 1(100)$ & S1 (100) \\
\hline Slope & S1 (100) & \multicolumn{2}{|c|}{$\mathrm{S} 1(100)$} & S1 (100) & $\mathrm{S} 1(100)$ & S1 (100) \\
\hline Drainage & S1 (100) & \multicolumn{2}{|c|}{ S1 (100) } & S1 (100) & $\mathrm{S} 1(100)$ & $\mathrm{S} 2(74)$ \\
\hline Texture & $\mathrm{S} 2(72)$ & \multicolumn{2}{|c|}{$\mathrm{S} 22_{1}(55)$} & S3 (54) & $\mathrm{S} 2(70)$ & S1 (100) \\
\hline Structure & $\mathrm{S} 2{ }_{1}(68)$ & \multicolumn{2}{|c|}{$\mathrm{S} 2(70)$} & $\mathrm{S} 2_{1}(65)$ & $\mathrm{S} 2(70)$ & S1 (95) \\
\hline Volume of coarse fragments & S1 (100) & \multicolumn{2}{|l|}{$\mathrm{S} 2_{1}(55)$} & & $\mathrm{S} 1(100)$ & S1 (100) \\
\hline Soil depth & S1 (100) & S3 (54) & $\mathrm{S} 3(53$ & & $\mathrm{S} 1(100)$ & S1 (100) \\
\hline $\mathrm{pH}\left(\mathrm{H}_{2} \mathrm{O}\right)$ & $\mathrm{S} 2(70)$ & S2 (70) & $\mathrm{S} 2(70$ & & $\mathrm{S} 2(70)$ & S1 (100) \\
\hline ECEC & S3 (54) & S3 (53) & $\mathrm{S} 2{ }_{1}(60$ & & $\mathrm{S} 2{ }_{1}(60)$ & S2 (94) \\
\hline Base saturation & S3 (52) & S3 (52) & $\mathrm{S} 2{ }_{1}(68$ & & $\mathrm{S} 2(70)$ & S1 (95) \\
\hline Organic carbon & N2 (19) & N2 (15) & $\mathrm{N} 2(19$ & & N2(19) & S1 (100) \\
\hline Available phosphorus & $\mathrm{S} 2_{1}(60)$ & $\mathrm{S} 2_{1}(60)$ & $\mathrm{S} 2{ }_{1}(65$ & & $\mathrm{S} 2{ }_{1}(65)$ & $\mathrm{S} 2_{1}(68)$ \\
\hline Aggregate suitability (\%) & & & & & & \\
\hline Potential & 64.53 & 47.40 & 35.62 & & 64.53 & 85.25 \\
\hline Actual & 16.90 & 10.72 & 10.68 & & 12.36 & 40.15 \\
\hline
\end{tabular}

Explanations of S1, S2, S2 $1, \mathrm{~S} 3, \mathrm{~N} 1$ and $\mathrm{N} 2$ are as stated in Table 3.

\section{CONCLUSION \& RECOMMENDATION}

Five different soils from two sites of the UNILORIN Sugar Research Farm (USRF) were characterized and classified according to Soil Taxonomy and the WRB for Soil Resources. Pedons I and IV were classified as Typic Haplustepts, Pedons II and III as Lithic Haplustepts and V as a Kanhaplic Haplustalf (Soil Survey Staff, 2014). With the WRB system, pedons I and IV were classified as Eutric Regosols (Arenic), II and III as Endo-Pisoplinthic Cambisols (Arenic) and $\mathrm{V}$ as a Gleyic Lixisol (Loamic).

Pedon $\mathrm{V}$ was rated best (highly suitable, $85.25 \%$ ) in terms of potential aggregate suitability for sugarcane cultivation. Pedons I and IV were rated moderately suitable $(64.53 \%)$. Pedon II was rated marginally suitable $(47.40 \%)$ while Pedon III was rated unsuitable $(35.62 \%)$. The main limitations of pedon II and pedon III were their shallow depths and high gravel contents. The aggregate suitability ratings of the soils from
USRF1 were very low due to their low fertility status and their sandy texture. The high sand content of these soils would predispose them to excessive leaching of nutrients and poor moisture retention. It would therefore be advisable to apply nutrients to the soils at USRF1 in split doses and at the time the crop would effectively absorb them.

Furthermore, supplementary provision of water would be required for the soils at USRF1 particularly towards the end of October when rainfall amounts decline. The soils from USRF1 were therefore rated as unsuitable for sugarcane cultivation. They could, however, be made suitable through fertilizer application, especially organic amendments, and good residue management practices as well as supplementary water supply through provision of appropriate irrigation. Pedon $\mathrm{V}$, on the other hand, was rated suitable for sugarcane production due its better fertility status and more favourable loamy texture. 


\section{REFERENCES}

Abekoe M.K. (1989). The Role of Concretions in Phosphorus Availability in a Typical Concretionary Soil of Northern Ghana. MPhil Thesis, Department of Soil Science, University of Ghana. http://ug.edu.gh

Abekoe M.K. and Sahrawat K.L. (2001). Phosphate retention and extractability in soils of the humid zone in West Africa. Geoderma, 102, 175-187

Ajiboye G.A., Alabi K.O., Adesodun J.K. and Aiboni V.U. (2011). Classification and suitability evaluation of the soils of a toposequence at Odeda, Ogun State for the production of rice (Oryza sativa). Nig. J. Soil Sci., 21 (2), 142-155

Ajiboye G.A., Jaiyeoba J.O., Olaniyan J.O. and Olaiya A.O. (2015). The characteristics and suitability of the soils of some major cocoa growing areas of Nigeria: Etung Local Government area of Cross River State. Agrosearch, 15 (1), 101-116. doi.org/10.4314/agrosh.v15i1.7

Blume H. (1985). Geography of Sugarcane, Verlag Dr. Albert Bartens, Berlin, pp. 1-21

Brady N.C. and Weil R.R. (2008). The Nature and Properties of Soils (14th ed.), Pearson Prentice Hall, NJ, p. 207

Bremner J.M. (1996). Nitrogen total. In: Sparks, D.L. (ed.), Methods of Soil Analysis, Part 3: Chemical Methods (pp. 1085-1122). Madison WI, Soil Sci. Soc. Am. Book Series No. 5

Buol S.W., Hole F.D., MaCracken R.J. and Southard R.J. (1997). Soil Genesis and Classification (4 $\left.{ }^{\text {th }} \mathrm{ed}.\right)$, Iowa State University Press, Ames, pp. 221-224

Chartres C.J. (1981). Land resources assessment for sugar-cane cultivation in Papua New Guinea. Appl. Geo., 1, 259-271

Cherubin M.R., Karlen D.L., Franco A.L., et al. (2016). A soil management assessment framework (SMAF) evaluation of Brazilian sugarcane expansion on soil quality. Soil Sci. Soc. Am. J., 80, 215-226

Cornland D., Johnson F., Yamba F., et al. (2001). Sugarcane Resources for Sustainable Development: A Case Study in Luena Zambia. Stockholm Environment Institute, Stockholm, p. 94

Dai Y., Qiao X. and Wang X. (2018). Study on cation exchange capacity of agricultural soils. IOP Conf. Series: Material Sci. Eng. DOI: 10.1088/1757-899X/392/4/042039

Esu I.E. (2005). Soil characterization and mapping for food security. Keynote Address, $29^{\text {th }}$ Ann. Conf. Soil Sci. Soc. Nigeria, Abeokuta, 6-10 Dec., 2005

Fábio R.M., Maria L.L., Eduardo D.A., Carlos E.V. and Marcelo C.S. (2008). Sugarcane crop efficiency in two growing seasons in São Paulo State, Brazil. Pesq. Agropec. Bras., (43), 11. DOI: 10.1590/S0100204X2008001100002

FAO AGL (2002). Crop water management. Agriculture Land and Water Division, Food and Agriculture Organization, Rome. Accessed: 23/07/2007: http://www. fao.org/ag/agl/aglw/cropwater/sugarcane.stm\#requirements

FAO (1976). A framework for land evaluation. Food and Agriculture Organization (FAO), Rome

FAO (1977). Guidelines for soil profile description ( $2^{\text {nd }} \mathrm{ed}$.), Soil Resources Development and Conservation Service, Land and Water Development Division, Food and Agriculture Organization (FAO), Rome

FAO (2006). Guidelines for soil description ( $4^{\text {th }}$ ed.). Food and Agriculture Organization (FAO), Rome

FAO (2007). Land evaluation towards a revised framework. Land and Water Discussion Paper No. 6. Food and Agriculture Organization (FAO), Rome

FPDD (1989). Fertilizer use and management practices for crops in Nigeria. Fertilizer Procurement and Distribution Division, Federal Ministry of Agriculture and Rural Development, Lagos, Nigeria, Series 2, p.188

Gee G. and Or G. (2002). Particle size. In: Dane J.H. and Topp G.C. (eds.), Methods of Soil Analysis, Part 4: Physical Methods (pp. 255-293). Madison WI: Soil Sci. Soc. Am. Book Series No. 5
Glyn J. (2004). Sugarcane. Blackwell Publishing, WileyBlackwell, Oxford, UK, p. 224

Gravois K. (2021). Sugarcane fertilizer recommendations for 2021. LSU AgCenter, USA

Griffee P. (2000). Ecology of sugarcane. Accessed from: www.ecoport.org/EP.exe\$EntFull?ID=1884, 15/06/2007

Haifa Group (2021). Using the right fertilizers in order to provide the sugar cane necessities. Matam-Haifa, 31905 Israel, https://www.haifa-group.com

Hermavan B. and Cameron K.C. (1993). Structural changes in a silt loam under long-term conventional or minimum tillage. Soil Till. Res., 26, 139-150

Hillel D. (2004). Introduction to Environmental Soil Physics, Soil Structure and Aggregation. Elsevier Science, USA, pp. 73-89

Igwe C.A., Akamigbo F.O.R. and Mbagwu J.S.C. (1999). Chemical and mineralogical properties of soils in southern Nigeria in relation to aggregate stability. Geoderma, 92, 111-123

IUSS Working Group WRB (2015). World Reference Base for Soil Resources 2014, Update 2015. Int. Soil Classification Sys. for Naming Soils \& Creating Legends for Soil Maps. World Soil Resources Report No. 106, FAO, Rome

Kanabo I., Halm A. and Obeng H. (1978). Phosphorus adsorption by surface samples of five iron pan soils of Ghana. Geoderma, 20, 299-306

Kingston G. (2014). Mineral nutrition of sugarcane. In: Moore P.H. and Botha F.C. (eds.), Sugarcane: Physiology, Biochemistry Functional Biology (Chap. 5). John Wiley \& Sons Inc. DOI: 10.1002/9781118771280.ch5

Kramer P.J. and Boyer J.S. (1995). Water Relations of Plants and Soils ( $1^{\text {st }}$ ed.), Academic Press, San Diego, CA, pp. 84-92

Langmaack M. (1999). Earthworm communities in arable land influenced by tillage, compaction, and soil. Zeitschrift für Ökologie und Naturschutz, 8, 11-21.

Lekwa M., Anene B. and Lekwa G. (2004). Chemical and morphological soil characteristics in drainage toposequence in Southeastern Nigeria. In: Ojeniyi S.O. et al. (eds.), Land Degradation, Agricultural Productivity and Rural Poverty, Environmental Implications (pp. 316-322). Proc. $28^{\text {th }}$ Ann. Conf. Soil Sci. Soc. Nig., National Root Crops Res. Inst., Umudike, Nigeria

Mahesh C., Rajeshwar N., Balaguruvaiah D. and Vidyasagar G. (2018). Genesis, classification and evaluation of some sugarcane growing black soils in semi-arid tropical region of Telangana. $J$. Pharmacog. Phytochem., 7, 81-92

McCray J.M., Morgan K.T. and Baucum L. (2019). Nitrogen fertilizer recommendations for sugarcane production for sugar on Florida sand soils. IFAS Extension, Univ. of Florida, SS-AGR-401, pp. 1-4

McLean E.O. (1982). Aluminum. In: A.L. Pages, R.H. Miller and D.R. Keeney (eds.), Methods of Soil Analysis, Part 2: Chemical Methods (pp. 978-998). Madison WI: Am. Soc. Agron.

Mistry P.S., Tripathi S. and Desai L.J. (2018). Response of sugarcane varieties to different levels of phosphorus application on yield and quality parameters of sugarcane under south Gujarat condition. Int. J. Chem. Stud., 9 (3), 1861-1863

Mubashir J., Raihan A. and Haroon S. (2017). Land suitability assessment for sugarcane cultivation in Bijnor district, India using geographic information system and fuzzy analytical hierarchy process. Geo. $J$. DOI: $10.1007 / \mathrm{s} 10708-017-9788-5$

Mwasinga G. (2018). Effects of Nitrogen Fertilizer on Yield and Quality of Introduced Sugarcane (Saccharum officinarum L.) Varieties in Commercial Fields at Kilombero, Morogoro Region, Tanzania. MSc Dissertation, Sokoine Univ. of Agric., Morogoro, Tanzania

Nelson D.W. and Sommers L.E. (1996). Total carbon, organic carbon organic matter. In: D.L. Sparks (ed.), Methods of Soil Analysis, Part 3: Chemical Methods (pp. 960-1010). Madison WI: Soil Sci. Soc. America Book Series No. 5, Am. Soc. Agron. 
Neswati R., Lopulisa C., Nathan M. and Ramlan. (2016). Land suitability index for estimating sugar can productivity in the humid tropics of south Sulawesi Indonesia. J. Trop. Soils, 21, 115-122

Nuga B.O., Eluwa N.C. and Akinbola G.E. (2008). Characterization and classification of soils along a toposequence in Ikwuano Local Government Areas of Abia State, Nigeria. Elect. J. Environ., Agric. Food Chem., 2779-2788

Nyamekye A.L. (1987). Phosphorus application to some selected savanna soils of Northern Ghana. Nyankpala Agric. Res. Ann. Report 1986/87, pp. 143-151

Obalum S.E., Watanabe Y., Igwe C.A., Obi M.E. and Wakatsuki T. (2013). Improving on the prediction of cation exchange capacity for highly weathered and structurally contrasting tropical soils from their fineearth fractions. Comm. Soil Sci. Plant Anal., 44 (12), 1831-1848. https://doi.org/10.1080/00103624.2013.790401

Obasi S., Osujieke D., Ahukaemere C., et al. (2016). Morphological properties of soils of three different toposequences under lain by dissimilar lithologies in Imo State, South-East Nigeria. Proc. 50 ${ }^{\text {th }}$ Ann. Conf. Agric. Soc. Nigeria, pp. 1037-1041

Ogunkunle A.O. (1993). Soil in land suitability evaluation: An example with oil palm in Nigeria. Soil use and management. J. Agric. Res. Dev., 9 (1), 35-40

Ogunkunle A.O. (2005). Soil survey and sustainable land management. Invited Paper, $29^{\text {th }}$ Ann. Conf. Soil Sci. Soc. Nigeria, Abeokuta, 6-10 ${ }^{\text {th }}$ Dec. 2005

Ogunwale J.A., Olaniyan J.O. and Aduloju M.O. (2009). Suitability evaluation of the University of Ilorin farmland for cowpea. Crop Res., 37 (1, 2 \& 3), 34-39

Okenmuo F., Anochie C., Ukabiala M., et al. (2020). Classification and assessment of agricultural potential of the lower Niger floodplain soils of Atani, southeastern Nigeria.Agro-Science, 19(3),51-61. DOI: 10.4314/as.v19i3.9

Olaniran O.J. (2002). Rainfall anomalies in Nigeria: The contemporary understanding. $55^{\text {th }}$ Inaugural Lecture, University of Ilorin, University Press, Ilorin, p. 66

Olaniyan J.O. and Ogunwale J.A. (2006). Suitability evaluation of Kusogi land in the sandstone-derived terrain of Niger State cashew (Anarcadium occidentale L.) production. J. Agric. Res. Dev., 5 (2), 140-152. DOI: 10.4314/jard.v5i2.42169

Oliveira R.I., de Medeiros M.R., Freire C.S., et al. (2016). Nutrient partitioning and nutritional requirement in sugarcane. Aust. J. Crop Sci., 10 (1), 69-75

Olsen S.R. and Sommers L.E. (1982). Phosphorus. In: D.L. Sparks (ed.), Methods of Soil Analysis, Part 2 (pp. 15-72). Madison WI, Am. Soc. Agron.

Osinuga O.A., Aiboni V.U. and Oyegoke C.O. (2020). Classification and suitability evaluation of soils along a toposequence for rice production in Alabata, Southwest Nigeria. Agro-Science, 19 (4), 43-50. DOI: 10.4314 /as.v19i4.8

Osujieke D.N., Obasi N.S., Imadojemu P.E., Ekawa M. and Angyu M.D. (2018). Characterization and classification of soils of Jalingo metropolis, Nigeria. Nig. J. Soil Sci., 28 (2), 72-80

Oteng J.W. and Acquaye D.K. (1971). Studies on the availability of phosphorus in representative soils of Ghana: Availability tests by conventional methods. Ghana J. Agric. Sci., 4, 171-183

Parfitt R., Giltrap J. and Whitton J. (1995). Contribution of organic matter and clay minerals to cation exchange capacity of soils. Comm. Soil Sci. Plant Anal., 26, 9-10. DOI: 101080/00103629509369376

Peng T., Fu J., Jiang D. and Du J. (2020). Simulation of the growth potential of sugarcane as an energy crop based on the APSIM model. Energ., 13, 2173. DOI: 103390/en13092173

Purseglove J.W. (1976). Tropical Crops: Monocotyledons ( $3^{\text {rd }}$ ed.), Longman Group Ltd., London, p. 607
Sajjad H., Nasreen I. and Ansari S. (2014). Assessing spatiotemporal variation in agricultural sustainability using sustainable livelihood security index: Empirical illustration from Vaishali district of Bihar, India. Agro-Ecol. Sustain. Food Sys., 38 (1), 46-68

Salako F.K. (2003). Susceptibility of coarse-textured soils to soil erosion by water in the tropics. Lecture, College on Soil Physics, Trieste, 3-21 Mar., LNS0418030

Saleem M., Ghaffar A., Anjum S., Cheema M. and Bilal M. (2012). Effect of nitrogen and growth and yield of sugarcane. J. Am. Soc. Sugar Cane Technol., 32, 75-93

Sanchez P.A. and Salinas J.G. (1981). Low input technology for managing oxisols and ultisols in tropical America. Adv. Agron., 34, 229-406

Schoeneberger P.J., Wysocki D.A., Benham E.C. and Soil Survey Staff. (2012). Field Book for Describing and Sampling Soils (Ver. 3.0), Natural Resour. Conserv. Service, National Soil Survey Center, Lincoln, NE

Schulze R., Maharaj M., Lynch S., Howe B. and MelvilThomson B. (1997). South African atlas of agrohydrology and climatology. Water Research Commission Report TT82/96, p. 276

Sobulo R.A. (1982). Soil tests and phosphorus requirements of maize on Alfisols in Nigeria. In: Puspharajah E. and Hamid. H. (eds.), Phosphorus and Potassium in the Tropics (pp. 191-202). Proc. Int. Conf. Phosphorus and Potassium in the Tropics, Kuala Lumpur, Malaysian Society of Soil Science

Soil Survey Staff (2014). Keys to Soil Taxonomy $\left(12^{\text {th }}\right.$ ed.), USDA-NRCS, Washington DC

Stewart G.A. (1968). Land evaluation. In: Stewart G.A. (ed.), Land Evaluation. Papers of CSIRO/UNESCO Symp., Canberra (pp. 1-10). Mac. Australia, Melbourne

Storie R. (1978). Index Soil Rating. University of California, Div. Agric. Sci., Special Publ. 3203, Oakland, CA

Subramani T., Sukumar K. and Priyanka S. (2017). Sugarcane modelling using GIS and remote sensing for Perambalur District. Int. J. Emerging Trend Technol. Comp. Sci., 6 (3), 208-218

Sys C., Van Ranst E. and Debaveye I. (1991). Land Evaluation, Part I: Principles in Land Evaluation and Crop Production Calculations. Gen. Admin. Dev. Coop., Agric. Publi., No. 7, Brussels-Belgium, p. 274

Tarimo A. and Takamura Y. (1998). Sugarcane production, processing and marketing in Tanzania. Afr. Stud. Monog., 19 (1), 1-11

Thangasamy A., Naidu M., Ramavatharam N. and Reddy C.R. (2005). Characterization, classification and evaluation of soil resources in Sivagiri micro-watershed of Chittoor district in Andhra Pradesh for sustainable land use planning. J. Indian Soc. Soil Sci., 53 (1), 11-21

Thomas G.W. (1982). Exchangeable cations. In: Page A.L., Miller R.H. and Keeney D.R. (eds.), Methods of Soil Analysis, Part 2: Chemical and Microbiological Properties (pp. 159-164). Madison, Wisconsin

Thomas G.W. (1996). Soil pH and soil acidity. In: Sparks D.L. et al. (eds.), Methods of Soil Analysis, Part 3: Chemical Methods (pp. 475-490). Madison WI: Soil Sci. Soc. Am. Book Series No. 5

US Salinity Laboratory Staff (1954). Diagnosis and Improvement of Saline and Alkali Soils. US Dept. Agric. Handbook 60, Washington, DC

van Diepen C., van Keulen H., Wolf J. and Berkhout J. (1991). Land evaluation: From intuition to quantification. In: Stewart B.A. (ed.), Advances of Soil Science Vol. 15 (pp. 139-204). Springer-Verlag, NY

Willy H. (2005). Evaluation of land use, land cover and land degradation: Verheye. Encyclopedia of Life Support Systems Vol. 1 (p. 331). Natl. Sci. Foundation Flanders, Belgium and Geo. Dept., Univ. of Gent, Belgium, ISBN: 978-1-84826-235-5(eBook)

Yates R.A. (1977). The environment for sugarcane. In: Land Evaluation Standards for Rainfed Agriculture. FAO World Soil Resource Report 46 